\title{
Identity of Asian Multinational Corporations: influence of tax havens
}

\author{
Vijay Pereira ${ }^{1} \cdot$ Yama Temouri $^{2,3} \cdot$ Chris Jones $^{2} \cdot$ Ashish Malik $^{4}$
}

Published online: 23 October 2019

(c) Springer Nature Limited 2019

\begin{abstract}
The sustained growth and importance of Asia as a hub of economic, social and political activity has attracted significant foreign direct investment and opportunities for economies from the West and other parts of the world to invest in this fast growing region. Regional headquarters and global innovation hubs of large multinational corporations (MNCs) are evidence of an Asian century phenomenon. The proliferation of tax havens in the region or the use of tax havens by firms in the Asian region is no surprise. This is evidenced through a complex and systematic policy choice by power coalitions, to facilitate their interests as well as trade and growth in the region. This proliferation has also had an impact on the changing identity of Asian MNCs in Asia. In this paper, we highlight this new and pervasive trend by presenting findings from recent research in the region on the topic of tax havens and identities of Asian MNCs.
\end{abstract}

Keywords Tax havens · Asia $\cdot$ Identity $\cdot$ Asian MNCs $\cdot$ Neo-liberalism $\cdot$ Economic growth

Vijay Pereira

vijay.pereira@port.ac.uk

Yama Temouri

y.temouri1@aston.ac.uk

Chris Jones

c.jones2@aston.ac.uk

Ashish Malik

ashish.malik@newcastle.edu.au

1 Khalifa University, Abu Dhabi, United Arab Emirates

2 Aston Business School, Aston University, Birmingham, UK

3 University of Wollongong in Dubai, Dubai, United Arab Emirates

4 Newcastle Business School, University of Newcastle, Callaghan, Australia 


\section{Introduction}

Asia is by far the largest and most populous of the world's continents. It encompasses $30 \%$ of the world's land area and, more importantly, $60 \%$ of the world's current population of 7.1 billion people. Economically, Asia drives global growth and over the last few decades, the continent has seen an exponential increase in its business activity. Large multinational corporations (MNCs) locate their headoffices in Asia or develop substantial regional subsidiary operations. The mature economies of Japan, Singapore and Malaysia, to name a few, are now being overshadowed by the newer economic giants such as China, India and South Korea in terms of world trade and the regional and global proliferation of their own MNCs (UNCTAD 2016; Hughes 2017). More specifically, the global shift towards offshoring, both services and manufacturing, has led to the emergence and increasingly vital role of these economies. Moreover, this economic shift in power has led not only to an increase in national GDP in the region, but has also seen the per capita income of people in this region improve significantly. Thus, the purchasing power of people in this region has been an attractive proposition for MNCs to not only operate in terms of manufacturing their goods and services and thereby benefitting from efficiency-seeking foreign direct investment (FDI) but also in terms of market seeking motives (see Dirlik 1992; Acharya 1997; Serrano 2017).

As emerging markets develop and the level of wealth grows ever higher, highnet-worth individuals and MNCs increasingly wish to protect their wealth in offshore locations to avoid income and corporation tax set by national governments. The establishment of tax haven subsidiaries by MNCs is one such creative manifestation of this and their widespread use has recently became a major global political issue. Tax havens allow MNCs to shift profits out of high tax jurisdictions and into low tax jurisdictions often via the use of complex transfer pricing techniques that take advantage of mismatches between rules and regulations that have been artificially created between countries. The attraction of a tax haven locations is not only the fact that taxation on corporate profits is very low (often zero) but also the fact that these locations offer a degree of secrecy that allow MNCs to hide financial flows of capital. The international business and management literature has only recently started to outline the ways in which the use of tax havens by MNCs is a different form of FDI compared to the standard forms of FDI identified in the literature (Beugelsdijk et al. 2010). In terms of evidence on the use of tax havens by MNCs, the literature offers cases and analysis from the Western world, but we have very limited evidence on such activity and its ramifications for Asia and other emerging countries (Buckley et al. 2015).

Moreover, what is interesting to investigate is the extent and role of emerging market MNCs (EMNCs) as well as developed country MNCs (DMNCs) concerning investing in tax havens within the Asian region. What we aim to investigate in this special issue are the causes and consequences of the emerging 'identity' that these EMNCs have developed in the context of tax havens. For example, how do EMNCs and DMNCs use tax havens in an Asian context compared to that in other parts of the world? In addition, does the Asian 'culture' mediate tax haven 
activity? Indeed, it is notable that many rich Asians are increasingly resorting to tax haven usage (Barron's 2016). Recently, the newly constituted Bank of Asiaa fully digital cross-border bank-had its official launch in 2018 in the British Virgin Islands, after being awarded the only banking licence in the region. Global giants Oracle, Avaloq and Saxo aid the Bank of Asia technologically. The bank was set up with a goal to service Asia's high-net-worth individuals, and several associated global offshore companies, many of which operate in the British Virgin Islands (of the approximately 2 million offshore companies in Asia). Of these, more than $40 \%$ of all offshore company owners are located in Greater China (Fintechnews 2018).

Another case is that of Indian businesses choosing Asian tax havens instead of Switzerland, the erstwhile and popular location of choice for parking savings and profits by Indian business and the political elite. According to the bilateral foreign holdings data released by the Bank of International Settlements (BIS), Indians tend to prefer Asian tax havens to Switzerland (Times of India 2017). The report further states that close to $53 \%$ of offshore Indian wealth is invested in tax havens within Asia such as Hong Kong, Macau, Singapore, Bahrain and Malaysia and only 31\% of the Indians have their wealth stored in Swiss banks. Taiwan is further seen as another destination for such activity (Tax Justice Network 2016), with Singapore leading the Asian group and among the global top five (Garcia-Bernardo et al. 2017; The Conversation 2017). According to the BIS report, wealth stored outside India rose to USD 62.9 billion in 2015, which is about 3.1\% of India's GDP in 2015. According to the National Bureau of Economic Research, the total offshore wealth in the world is estimated to be USD 8.6 trillion, which is about $11.6 \%$ of the world's GDP. Indeed, in this special issue Mukundhan et al. (2019) highlight the drivers of Indian MNCs investing in tax havens, including for tax evasion purposes and taking benefit of the secrecy that these tax haven jurisdictions offer, but also for gaining access and efficiency in global markets.

Overall, from an Asian perspective and context, the leading tax haven destinations are identified as Hong Kong, Singapore, Malaysia, Bahrain and Qatar, with Indonesia and Thailand as two other emerging destinations (Wall Street Journal 2016; ICO Services 2016). It is under this backdrop that this special issue investigates MNC behaviour with specific relevance to the Asian region and the impact it has had on firm identity in the region. More specifically, we have accepted three unique value-adding papers that portray the 'story' of tax havens from an Asian perspective. These papers tell the story from a Chinese, Indian and Asia-Pacific regional context.

Before we delve any further on the variations, utilisation and proliferation of tax havens in the Asian region, we provide some theoretical review of the literature on identities of MNCs in the backdrop of a strong neo-liberal agenda that has intensified in the short history of globalisation. A historical background is not only desirable but it is essential to understanding the deeper undercurrents at play in the nexus between business and the political elite that have led to the emergence and resurgence of what we now know of as tax havens. To this end, we highlight the trend of certain economic policy-making that have led to a small proportion of earners amassing substantial wealth through legitimised political and legal mandates. This 
is typical of neo-liberalism agendas of the state in promoting deregulation, privatisation and a strong pro-market ethos at a national and international level, often precluding such acts from democratic decision-making (Lesage and Vermeiren 2011) or what Gill (2008) notes as the "new constitutionalism of disciplinary neo-liberalism". This trend is not a new phenomenon and has been in existence, since early 1600s when the erstwhile East India Company was established to undertake trade in the East Indies (Pereira and Malik 2015; Malik 2018a). The early roots of a neoliberal agenda were evident, in what some would describe as the first true MNC, when this relatively small organisation of well-connected people formed a powerful coalition to exploit and maximise wealth through sustained efforts of colonisation.

The following section briefly reviews the emergence of a neo-liberal agenda and associated economic policy-making, among which, the emergence and proliferation of Tax havens is one such political and economic program. Then, we briefly review the emergence of a new order-neo-liberalism. This is followed by our critical analysis of the emergence of a new and different identity by MNCs that is influenced by the adoption and use of tax havens. Next, we present a review of the key contributions from Asia in the form of three papers in this special issue and we conclude with implications for theory and practice.

\section{The Neo-liberal agenda and tax havens}

The critical analysis by Chomsky's evergreen account (1999): Profit over people: Neoliberalism and global order, highlights, using examples from the US and other Anglo-Saxon nations, how the Washington Consensus is a prime example of the nexus between the state and industry to actively pursue and implement market-oriented policies and programs. Chomsky also notes several historical examples from Mexico, Brazil and India where such attempts are well documented, including that of the excesses carried out by the East India Company. While there is nothing inherently wrong with the nature of such market-oriented policies, there is little evidence of its sustained success in a number of nation states. What often results through such approaches, as also confirmed by Krugman's (2009) fierce account of the neo-liberal ideology, is that a vast majority of the population is affected by the quick, often illinformed, and generally unexplained decisions by a small group of individuals. Further, owing to the high levels of information asymmetry, those affected by such decisions are often left wondering about the benefits. If the program of market-oriented policies succeeds, the decision-makers are the first ones to claim the high moral ground and reinforce they logic with a greater vitality. In cases of failure, of which there are plenty, the decision-makers often blame others for the lack of adequate information (Malik 2018b).

Examples of a dominant neo-liberal agenda from recent history have all been well documented. For example, Stiglitz's account (2010) provides a systematic account of how the economic misadventure of the global financial crisis was engineered in conjunction with a number of influential political, business and institutional leaders. Of course, the adverse impacts of these hurt all segments of the economy, but the beneficiaries of the reconstruction and bailout were also the business segments who 
contributed to the crisis in the first place. This reinforces how the neo-liberal agenda is dominant and continues to strengthen its grip over a range of social and economic policy-making programs, under the guise of reformist and market-oriented policies.

With respect to the linkage between neo-liberalism and the emergence of tax havens, building on Gill's (2008) argument of new constitutionalism of disciplinary neo-liberalism, Lesage and Vermeiren (2011) highlight how the progressive adoption of new constitutional arrangements at domestic and international levels have led international banking, trade and financial institutions such as the World Trade Organisation, (WTO), International Monetary Fund (IMF) and Organisation for Economic Cooperation and Development (OECD) to go above and beyond their remit to support the neo-liberal agendas of the developed nations. Lesage and Vermeiren (2011) further highlight how tax havens have extended the systematic support to wealthy individuals and firms to design and implement structured investment vehicles in geographies that were immune of regulatory scrutiny. With the increased awareness and proliferation of this agenda, a number of international business and political leaders have started to form a coalition to bring about changes that are only benefitting the tax evading and tax minimisation strategies of select individuals and firms (Lesage et al. 2010). This stands in stark contrast to the efforts by the OECD BEPS initiative in combating tax haven activity.

\section{Tax havens and the identity of Asian MNCs}

There is significant diversity in thought and action across Asian, European and US MNCs and their strategies in dealing with adverse economic events in the aftermath of the global financial crisis. For example, some MNCs demonstrate behaviour ranging from highly ethical, long-term and conservative thinking to more short-term, profit maximisation and unethical decisions to serve ones interest (Malik 2013, 2018b). Hence, we can infer points of difference in MNC identity, which is in part informed by the ownership structures and the nature of managerial talent employed. Indeed, a recent special issue by Pereira and Malik (2018) captured the various identities of MNC globally. For example, Sharma et al. (2018) evaluate MNC's identity through leveraging the shared identity of "Australianness" and "Indianness" in conducting business in India. The identities of MNCs can be shaped through different drivers, environments, local and foreign influences, cultures, institutions, firm leadership, etc. Over time, a specific MNC identity gets socialised, institutionalised and legitimised. Such MNC identity dilemmas persist because of the volatility, complexity and dynamism these MNC face in today's globalised world (see Munjal et al. 2018 for different MNC identity dilemmas). Another example by Patnaik et al. (2018) investigates the identity of the world's largest gold mining company from the US when operating in an emerging country, such as Ghana.

In view of the arguments made above, we note the paucity of literature analysing how tax haven behaviour of MNCs influences identity formation. For example, an MNC may portray, on the one hand, a strong corporate social responsibility (CSR) image through its various deeds (Drucker 1984; Carroll 1999; Lorenzo-Molo 2009), but on the other hand, it may well undertake financially less ethical activities, such 
as tax haven investments (Oxelheim et al. 2001; Eden 2009). In such scenarios, how would the MNC stakeholders perceive an MNC's identity? More specifically, how would other MNCs perceive a particular MNC that utilises tax havens? How would key stakeholders such as customers, suppliers, employees and communities respond to such activity?

Based on the above discussion, we now explore the impact of a neo-liberal agenda and other influences in specifically shaping identity of MNCs from the three contributions we have selected for this special issue. It is worth noting that there is and will still be diversity in MNC identity even when emanating from the same geography and their approach towards the use of tax havens.

\section{Understanding Chinese MNC identity}

The first contribution, by Sutherland et al. (2019), explores the role of tax havens and offshore financial sectors with respect to Chinese FDI. The authors outline in detail how capital flows are routed between mainland China and a number of tax haven locations. In Table 2 of their paper, using data from China's Outward FDI Bulletin (2016) they show that Hong Kong is the top destination for Chinese outward FDI with the annual flow at $\$ 114.2$ dollars; this is followed by outward FDI to the US ( $\$ 17$ billion), Cayman Islands ( $\$ 13.5$ billion) and the British Virgin Islands (13.5 billion). According to the Tax Justice Networks' 2018 Financial Secrecy index (Cobham and Janský 2018) which ranks jurisdictions according to their secrecy and scale of their offshore financial activities, each of these destinations ranks very highly in terms of secrecy. For example, The Cayman Islands is ranked third in the index and Hong Kong is ranked fourth. Sutherland et al. (2019) further discuss how special purpose entities (SPEs) play such a prominent role in terms of the organisational structures Chinese firms use to route offshore capital.

Interestingly, the authors point out that these flows are not just round tripping FDI, where capital flows out and then back into the mainland, but also "onward-journeying" FDI (Sutherland and Ning 2011). Where this type of FDI involves: "establishing an offshore business (often an SPE) and using this vehicle to conduct further FDI into third countries". Due to this, Sutherland et al. (2019) state that "investment made via SPE to third countries, are not recorded at all in official Chinese outward FDI data, rather they are recorded as outward FDI from the tax haven in which the SPE is formed". It is this fact, which suggests that there are genuine problems with using FDI data to measure MNC. This is the case in terms of identifying the ultimate geographical destination of FDI, as well as its targeted industrial sector. It is also this fact that provides the rationale for the remainder of this important paper.

By reviewing the current leading IB literature that studies outward FDI from China (with a focus on work published in the Journal of International Business Studies), the authors shine a spotlight on the fact that much of it seems to largely ignore the role of tax havens. They state "as a result the findings of most of the studies of Chinese MNCs are likely to be heavily contaminated by the incorrect inclusion of some SPE-related subsidiaries as well as by the exclusion of some genuine value-adding ones". This insight builds upon an important paper by Beugelsdijk 
et al. (2010) that also discusses systematic biases in the measurement of MNC affiliate activity.

At the end of this paper, the authors clearly outline a roadmap forward by outlining the key lessons learned and points to new directions that the literature my wish to take. Indeed, they argue that replication studies that incorporate a proper understanding of the role of offshore may allow a more reliable understanding of Chinese FDI identity in this context. The above evidence identifies a trend towards a risk-diversification strategy employed by Chinese MNCs in selecting their choice of tax havens, with the highest level of trust, measured by the value of outward FDI to be close to their administrative control, i.e. in Hong Kong. The above trend also highlights the challenges of transparency in objectives of Chinese MNCs as part of its identity through its extensive outward FDI using SPEs in other countries.

\section{Patterns and drivers of Indian investments in tax havens}

The second contribution by Sahasranamam and Colleague (2019) focuses on Indian outward FDI into tax havens between the years 2007 to 2017. The authors show that, in contrast to quite volatile movements in overall Indian outward FDI, tax haven FDI has been relatively stable over this period. It is not surprising that the top tax haven destination for Indian MNCs is Mauritius where round tripping has become pervasive. Due to the attractiveness of Mauritius as a top tax haven destination, the Indian government has renegotiated its bilateral tax treaty with the island and introduced a General Anti Avoidance Rule (GAAR) to try to curb profit shifting. Other important destinations for Indian outward FDI include the other well-known tax havens, namely the British Virgin Islands, the Cayman Islands and Cyprus. The authors outline interesting trends with respect to the types of MNCs who invest in tax havens, which partially confirm previous research. They find no systematic pattern as to whether firm age is linked to tax haven use; however, firms that are more international (in terms of the number of overseas subsidiaries they own) were found to be more tax aggressive.

Furthermore, the authors find that in terms of capitalising their investments in tax havens, the most preferred route is via bank guarantees. Indeed, manufacturing MNCs find this method particularly popular. One of the novel features of this research is the fact that the authors utilise a granular firm-level dataset from the Reserve Bank of India. This means that they are able to provide raw statistics for tax haven investments by firms and in the paper, they actually list the top 15 Indian firms in terms of tax haven FDI-almost all of which are private organisations and are often owned by Indian business groups. These findings are very interesting as they are similar to the Korean chaebols (e.g. Lim 2011; Baek et al. 2006). The similarity to their Korean counterparts lies in the fact that Indian business groups engage extensively in intra-group sales, and hence it is not surprising that they are strongly linked to investments in tax haven locations.

Other interesting findings from the paper suggest that the main FDI motive for Indian firms investing in tax havens is based on efficiency-seeking FDI and this corroborates with previous findings by Desai et al. (2006). Complementing their 
detailed trend analysis, the authors provide multivariate regression results showing that firms with higher corporate tax bills are more likely to invest in tax havens and MNCs with higher liquidity are more likely to use tax havens. These results offer evidence for the efficiency arguments that the authors make, instead of the reputational implications, for which they do not find evidence.

In their conclusion, the authors discuss avenues for future research with a particular emphasis on the impact of policy. They argue that current policy seems to be having its desired effect because tax haven investment into the popular tax haven destinations seems to have declined in recent years, but they signal that there could be a situation where Indian firms are beginning to shift to other locations such as Jersey and Panama. This demonstrates why tax policy must have a global dimension to it because if countries only aim to renegotiate bilateral tax treaties with countries that currently threaten their tax base, it will not be long before other tax havens spring up to take their place. The above pattern of FDI investments and use of tax havens by Indian MNCs suggests its concentration in the private sector and driven by large Indian business houses. The efficiency-seeking motive of Indian MNCs is not unique to Indian firms; however, those that have higher levels of liquidity in their cash flows are likely to use tax havens extensively. It would be interesting to keep an eye on the future, to see if this trend continues or deviates.

\section{Asia-Pacific tax haven networks}

The third contribution by Martinus et al. (2019) applies a network analysis of the firm-subsidiary connections of firms listed across five stock exchanges of the AsiaPacific region. They find considerable variation in the complexity of corporate structures and that the prevalence of tax havens within them plays a prominent part. They argue that there is a dearth of literature on the geographical drivers related to tax havens and offshore financial centres and with respect to the IB literature, this is unsurprising given the fact that the "location" component of the OLI paradigm has been somewhat neglected (Dunning 2014; Buckley 1985). Methodologically, the authors use parent-subsidiary locational data to map the geographic ties of MNC networks. Hence, they adapt previous work on 'world city network' research (see Alderson et al. 2010; Hennemann and Derudder 2014; Krätke 2014; Sigler and Martinus 2017). Five corporate networks are constructed from a database of headquarters and subsidiary links for firms listed on five Asia-Pacific stock exchanges: (1) Australia Securities Exchange (ASX); (2) Bombay Stock Exchange (BSE); (3) Shanghai Stock Exchanges (SSE); (4) Shenzhen Stock Exchange (SZSE); and (5) the Tokyo Stock Exchange (TSE). In total therefore, 9451 parent firms are included that have links to 193,322 subsidiaries.

Overall, the authors find that the five networks present similarities and differences in the way in which nations globalise and interact with tax havens. Firms listed on the Australian and Japanese exchanges have much more complex structures relative to Chinese and Indian firms. Interestingly, there appears little variation in the degree of engagement with tax havens across the five networks. This is an interesting finding and suggests that tax havens are equally attractive to firms across the 
heterogeneous Asia-Pacific region. However, the authors find that the geographic distribution of the links with tax havens for each network differs. Firms listed on the Chinese exchange have greater links with Hong Kong and the 'Bermuda Triangle' that encompasses the BVI, Bermuda and Cayman Islands, while Indian firms listed on the Bombay exchange have much greater ties to the UAE and Mauritius. Again, as noted in the case of Chinese and Indian MNC's first preference, there is an affinity and degree of influence and strength of ties to the mainland with a tax haven geography. For example, Hong Kong is a preferred destination for Chinese MNCs and Indian MNCs prefer Mauritius. There seems to be an emerging pattern affecting these Chinese and Indian MNCs, respectively, when it comes to their choice and this in some ways reflects that identity, affinity and network ties are critical aspects in shaping MNC identity in their use of tax havens. This is understandable as without such network ties and affinity advantages a regional or an international neo-liberal agenda would be difficult to implement.

\section{Summary and outlook}

This special issue offers some new perspectives on EMNCs from the Asian region and their behaviour with respect to tax haven activity. However, the task of investigating the link between EMNC use of tax havens, corporate social responsibility and governance practices and its impact in shaping their perceived identity is not an easy one. To this end, the set of contributions in this special issue have made an initial attempt to try to unbundle how MNCs create their identity. However, there is much more that needs to be uncovered in terms of the process and its influences, for example, based also on MNC ownership, industry affiliation, customer base, cultural values, government backing, mergers and acquisitions (M\&A), and internationalisation strategies (Yu et al. 2015).

MNCs may portray, on the one hand, a very good corporate social responsibility (CSR) image through its various deeds (Drucker 1984; Carroll 1999; LorenzoMolo 2009), but on the other hand, it may well undertake financially less ethical or responsible activities, such as tax haven investments (Oxelheim et al. 2001; Eden 2009). In such scenarios, how would the stakeholders of an MNC perceive this type of identity? How would other alliance partners perceive a MNC that utilises tax havens? How would key stakeholders such as customers, suppliers, employees, communities respond to such activity?

Another area of interest for this special issue relates to the large body of literature, which has examined the use of transfer pricing techniques by MNCs from developed countries to shift profits into jurisdictions that provide low levels of corporate tax and legislation that allows a significant level of secrecy for both individuals and firms (Eden 2009). However, is this the case for Asian MNCs? What jurisdictions do Asian firms strategically target and are there differences across regions, countries and industry? (Chen and Ku 2002). A recent study by Jones and Temouri (2016) show that for developed economy MNCs, the variety of capitalism matters in explaining the likelihood of an MNC utilising a tax haven subsidiary (Hall and Soskice 2001; Loveridge 2006; Meyer and Peng 2016). So, do firms from the 
Asian region, who have links with the liberal market economics of the UK and US, show increasing tax aggressiveness compared to those firms who have links with the coordinated market economies of Germany, Austria and the Nordic countries? (see recent work by Pereira et al. 2017 on mapping the impact of Asian business systems on HRM and organisational behaviour). Also, how does corporate governance at the firm-level matter, such that there are greater regulatory and tax arbitrage opportunities for MNCs that have a particular ownership type and structure (e.g. business groups)? (Yiu et al. 2013). Last, but not least, do institutional factors across countries drive tax and regulatory arbitrage, such as the level of corruption? (Lee et al. 2014). In conclusion, we hope that this special issue builds a solid platform for future researchers to investigate some of these probing questions. Indeed, the role of tax haven use and by MNCs will increasingly play a more prominent part in the international business and management literature in the future. The challenge is to unbundle and investigate this complex, but important phenomenon.

\section{References}

Acharya, A. (1997). Ideas, identity, and institution-building: From the 'ASEAN way' to the 'Asia-Pacific way'? The Pacific Review, 10(3), 319-346.

Alderson, A., Beckfield, J., \& Sprague-Jones, J. (2010). Intercity relations and globalization: The evolution of the global urban hierarchy, 1981-2007. Urban Studies, 47(9), 1899-1923.

Baek, J. S., Kang, J. K., \& Lee, I. (2006). Business groups and tunneling: Evidence from private securities offerings by Korean chaebols. The Journal of Finance, 61(5), 2415-2449.

Barron's. (2016). Why Asia's rich really use tax havens? https://www.barrons.com/articles/why-asias -rich-really-use-global-tax-havens-1460420954

Beugelsdijk, S., Hennart, J.-F., Slangen, Q., \& Smeets, R. (2010). Why and how FDI stocks are a biased measure of MNE affiliate activity. Journal of International Business Studies, 41(9), 1441-1459.

Buckley, P. (1985). A critical view of theories of the multinational enterprise. In P. Buckley \& M. Casson (Eds.), The economic theory of the multinational enterprise (pp. 1-19). London: Palgrave Macmillan.

Buckley, P., Sutherland, D., Voss, H., \& El-Gohari, A. (2015). The economic geography of offshore incorporation in tax havens and offshore financial centres: The case of Chinese MNCs. Journal of Economic Geography, 15(1), 103-128.

Carroll, A. B. (1999). Corporate social responsibility evolution of a definitional construct. Business \& Society, 38(3), 268-295.

Chen, T. J., \& Ku, Y. H. (2002). Creating competitive advantages out of market imperfections: Taiwanese firms in China. Asian Business \& Management, 1(1), 79-99.

Cobham, A., \& Janský, P. (2018). Global distribution of revenue loss from corporate tax avoidance: Reestimation and country results. Journal of International Development, 30(2), 206-232.

Desai, M. A., Foley, C. F., \& Hines, J. R., Jr. (2006). Do tax havens divert economic activity? Economics Letters, 90(2), 219-224.

Dirlik, A. (1992). The Asia-Pacific idea: Reality and representation in the invention of a regional structure. Journal of World History, 3(1), 55-79.

Drucker, P. F. (1984). The new meaning of corporate social responsibility. California Management Review, 26(2), 53-63.

Dunning, J. (2014). Location and the multinational enterprise: A neglected factor?. In Location of international business activities (pp. 35-62). London: Palgrave Macmillan.

Eden, L. (2009). Taxes, transfer pricing and the multinational enterprise. In A. M. Rugman (Ed.), The Oxford handbook of international business (2nd ed., pp. 557-590). Oxford: Oxford University Press. 
Fintechnews. (2018). Bank of Asia launches fully digital offshore banking from a tax haven. http://finte chnews.sg/21490/wealthtech/bank-of-asia-launches-fully-digital-offshore-banking-from-a-tax-haven /

Garcia-Bernardo, J., Fichtner, J., Takes, F. W., \& Heemskerk, E. M. (2017). Uncovering offshore financial centers: Conduits and sinks in the global corporate ownership network. Scientific Reports, 7(1), 6246.

Gill, S. (2008). Power and resistance in the new world order. 2nd Edition, fully revised and updated. Houndmills Basingstoke: Palgrave Macmillan.

Hall, P. A., \& Soskice, D. (2001). Varieties of capitalism: The institutional foundations of comparative advantage. Oxford: Oxford University Press.

Hennemann, S., \& Derudder, B. (2014). An alternative approach to the calculation and analysis of connectivity in the world city network. Environment and Planning B, 41(3), 392-412.

Hughes, C. W. (2017). Japan's rise and fall (and rise again) in The Pacific Review. The Pacific Review, $30(6), 1-10$.

ICO Services. (2016). Top 5 offshore jurisdictions in Asia. https://www.icoservices.com/news/top-5-offsh ore-jurisdictions-asia.html\#takeaway

Jones, C., \& Temouri, Y. (2016). The determinants of tax haven FDI. Journal of World Business, 51(2), 237-250.

Krätke, S. (2014). Global pharmaceutical and biotechnology firms' linkages in the world city network. Urban Studies, 51(6), 1196-1213.

Krugman, P. (2009). The conscience of a liberal. New York: WW Norton \& Company.

Lee, Y., Hemmert, M., \& Kim, J. (2014). What drives the international ownership strategies of Chinese firms? The role of distance and home-country institutional factors in outward acquisitions. Asian Business \& Management, 13(3), 197-225.

Lesage, D., McNair, D., \& Vermeiren, M. (2010). From Monterrey to Doha: Taxation and financing for development. Development Policy Review, 28, 155-172.

Lesage, D., \& Vermeiren, M. (2011). Neo-liberalism at a time of crisis: The case of taxation. European Review, 19(1), 43-56.

Lim, Y. (2011). Tax avoidance, cost of debt and shareholder activism: Evidence from Korea. Journal of Banking \& Finance, 35(2), 456-470.

Lorenzo-Molo, M. C. F. (2009). Why corporate social responsibility (CSR) remains a myth: The case of the Philippines. Asian Business \& Management, 8(2), 149-168.

Loveridge, R. (2006). Developing Institutions- 'Crony capitalism' and national capabilities: a European perspective. Asian Business \& Management, 5(1), 113-136.

Malik, A. (2013). Post-GFC people management challenges: A study of India's information technology sector. Asia Pacific Business Review, 19(2), 230-246.

Malik, A. (2018a). Strategic human resource management and employment relations: An international perspective. Singapore: Springer Nature.

Malik, A. (2018b). Human resource management and the global financial crisis: Evidence from India's IT/BPO industry. UK: Routledge.

Martinus, K., Sigler, T., Iacopini, I., \& Derudder, B. (2019). The role of tax havens and offshore financial centers in Asia-Pacific Networks: Evidence from firm-subsidiary connections. Asian Business \& Management, forthcoming.

Meyer, K. E., \& Peng, M. W. (2016). Theoretical foundations of emerging economy business research. Journal of International Business Studies, 47(1), 3-22.

Mukundhan, K. V., Sahasranamam, S. \& Cordeiro, J. 2019. Corporate investments in tax havens: Evidence from India, Asian Business \& Management, forthcoming.

Munjal, S., Budhwar, P., \& Pereira, V. (2018). A perspective on multinational enterprise's national identity dilemma. Social Identities, 24(5), 548-563.

Oxelheim, L., Randøy, T., \& Stonehill, A. (2001). On the treatment of finance-specific factors within the OLI paradigm. International Business Review, 10(4), 381-398.

Patnaik, S., Temouri, Y., Tuffour, J., Tarba, S., \& Singh, S. K. (2018). Corporate social responsibility and multinational enterprise identity: Insights from a mining company's attempt to localise in Ghana. Social Identities, 24(5), 604-623.

Pereira, V., \& Malik, A. (2015). Making sense and identifying aspects of Indian culture(s) in organisations: Demystifying through empirical evidence. Culture and Organization, 21(5), 355-365.

Pereira, V., \& Malik, A. (2018). Identities in transition: The case of emerging market multinational corporations and its response to glocalisation. Social Identities, 24(5), 533-547. 
Pereira, V., Malik, A., \& Froese, F. J. (2017). Mapping the impact of Asian business systems on HRM and organisational behaviour: Multi-level comparative perspectives. Journal of Asia Business Studies, 11(3), 253-261.

Serrano, L. O. (2017). The Pacific alliance and the construction of a new economic regime? In J. Briceño \& I. Morales (Eds.), Post-hegemonic regionalism in the Americas: Toward a Pacific-Atlantic divide? (p. 141). New York: Routledge.

Sharma, N., Boyle, B., Mitchell, R., Malik, A., Gray, S., \& O’Mahony, B. (2018). Leveraging the common and outsourcing the distinct: Institutional difference and multinational company identity in emerging economies. Social Identities, 24(5), 564-581.

Sigler, T., \& Martinus, K. (2017). Extending beyond 'world cities' in World City Network (WCN) research: Urban positionality and economic linkages through the Australia-based corporate network. Environment and Planning A, 49(12), 2916-2937.

Stiglitz, J. E. (2010). Freefall: America, free markets, and the sinking of the world economy. New York: WW Norton \& Company.

Sutherland, D., Hennart, J. F., \& Anderson, J. R. (2019). How does the routing of FDI to and via tax havens confound our understanding of Chinese MNE identity? A critical review the empirical literature on Chinese MNEs. Asian Business \& Management, forthcoming.

Sutherland, D., \& Ning, L. (2011). Exploring 'onward-journey' ODI strategies in China's private sector businesses. Journal of Chinese Economic and Business Studies, 9(1), 43-65.

Tax Justice Network. (2016). Taiwan-the un-noticed Asian tax haven? Tax Justice Network Blog. https:// www.taxjustice.net/2016/02/10/taiwan-the-un-noticed-asian-tax-haven/

The Conversation. (2017). These five countries are conduits for the world's biggest tax havens. https:// theconversation.com/these-five-countries-are-conduits-for-the-worlds-biggest-tax-havens-79555

Times of India. (2017). Indian offshore wealth parks itself in tax havens of Asia. https://timesofindia.india times.com/business/india-business/indian-offshore-wealth-parks-itself-in-tax-havens-of-asia/artic leshow/60504767.cms

UNCTAD. (2016). World investment report. Geneva: Investor Nationality: Policy Challenges.

Wall Street Journal. (2016). The Tiny Malaysian Island that wants to be a tax haven. https://www.wsj. com/articles/malaysian-island-works-offshore-niche-1464847210

Yiu, D. W., Ng, F. W., \& Ma, X. (2013). Business group attributes and internationalization strategy in China. Asian Business \& Management, 12(1), 14-36.

Yu, A., Ding, H. B., \& Chung, H. M. (2015). Corporate social responsibility performance in family and non-family firms: The perspective of socio-emotional wealth. Asian Business \& Management, 14(5), $383-412$.

Publisher's Note Springer Nature remains neutral with regard to jurisdictional claims in published maps and institutional affiliations. 